\title{
New or Noteworthy Trees from Micronesia. XXII.
}

\author{
By \\ Ryôzô Kanehira and Sumihiko Hatusima.
}

With 2 Text-figures.

Received Aprit 1, 1939.

(209) Hanguana malayana Merrill in Philip. Journ. Sci. Bot. 10 (1915) 3.

Veratronia malayana Miquel Fl. Ind. Bat. 3 (1859) 553.

Susum malayanum Planchon ex Hooker f. Fl. Brit. Ind. 6 (1892) 391 ; Lauterbach in ENGL. Bot. Jahrb. 50 (1913) 289.

Hanguana aquatica Kanemra in Journ. Nat. Hist. Soc. Formos. 25 (1935) 8, f. 10, Enum. Micr. Pl. (1935) 286, syn. nov.

Hab. Palau. Vern. name: Choeis. Distrib. Malaya and N. New Guinea.

(210) Oxytenanthera Warburgii K. Schumann ex Volkens in Engl. Bot. Jahrb. 31 (1901) 457; K. Schumann et K. Lauterbacir Nacht. Fl. Deutsch. Schutzg. Süds. (1905) 59; Hosokawa in Journ. Soc. Trop. $\Lambda$ gr. Taihoku 7 (1935) 324, pro parte.

Schizostachyum lima sensu Kanehira in Bot. Mag. Tokyo 45 (1931) 273, Enum. Micr. Pl. (1936) 273, pro parte, non MerriLl.

Hab. Yap and Palau. Distrib. New Guinea and Key Islands.

(211) Bentinckiopsis carolinensis BECCARI in Webbia 5 (1921) 113; Engl. Bot. Jahrb. 59 (1924) 16; KaneH. in Bot. Mag. Tokyo 45 (1931) 274 ; Burret in Notiz. Bot. Gart. Mus. Berl.-Dahlem 12 (1935) 593.

Cyphonokentia (?) carolinensis BEcc. in ENGL. l. c. 4 (1915) 52.

Exorrhiza carolinensis BurRet, Fedde Repert. 24 (1926) 296; KaneII. in Bot. Mag. Tokyo 48 (1934) 731.

Hab. Truk. Distrib. Endemic.

(212) Bentinckiopsis ponapensis BeCCARI in Webbia 5 (1921) 113; Kaneh. Fl. Micr. (1933) 72, f. 9 ; Burret l. c. 594.

Exorrhiza ponapensis Burret, Fedde Repert. 24 (1926) 294; KaneH. in Bot. Mag. Tokyo 48 (1934) 732, Enum. Micr. Pl. (1936) 284.

Hab. Ponape. Distrib. Endemic. 
(213) Pseudopinanga insignis (Becc.) Burret in Notiz. Bot. Gart. Mus. Berl.-Dahlem 13 (1936) 194.

Pinanga insignis Becc. in Philip. Journ. Sci. 2 (1907) 223; Merr. Enum. Philip. Fl. Pl. 1 (1922) 165.

Glubiopsis palauensis sensu KANEII. in Bot. Mag. Tokyo 45 (1931) 274, Fl. Micr. (1933) 76, f. 11, Enum. Micr. Pl. (1936) 284, non Beccari.

Pinanga micronesica Kaner. in Journ. Jap. Bot. 12 (1935) 635, f.l.

Hab. Palau. Distrib. Philippines.

(214) Clitandropsis insularis Markgraf in EngL. Bot. Jahrb. 63 (1930) 281; Kaneh. Enum. Micr. Pl. (1936) 396, (fig. 78).

Ad descriptionem addenda: Bacea globosa, eirc. 3-4 cm. diametro, aurantiaca intus pulpa carnosa replecta, pulpa nidulantia fuscescentia, semina numerosa, ovato-oblonga vel oblonga vel ovata circ. $1.2-1.4 \mathrm{~cm}$. longa. Albumen carnosum pallide viridescente, cotyledones lineari-oblongae, radicula brevi.

No. 4721 (fr.) Marakal. near Korror, Palau, S. Hatusima, April 7, 1938 ; no. 4953 (fl.) Ruis Almonogui, Palau, S. Hatusima April 14, 1938. A liana, $3 \mathrm{~cm}$. in diameter. Distrib. Endemic.

(215) Kentrochrosia carolinensis (KaneH.) Kanehira et Hatusima comb. nov. (fig. 79).

Kopsia carolinensis Kaner. in Bot. Mag. Tokyo 45 (1931) 344, Enum. Micr. Pl. (1936) 395.

Ad descriptionem addenda: Drupa subrhomboidea, complanata, apice longe acuminata basi acuta valide calcarata, canaliculata circ. $3 \mathrm{~cm}$. longa, $1.8 \mathrm{~cm}$. lata, semina compressa, ovato-oblonga, utrinque acuminata circ. 2 cm. longa, $0.8 \mathrm{~cm}$. lata.

No. 4569 (flos \& fr.) Gaspan, Babeldaob, Palau, R. Kanemira \& S. Hatusima, April 3, 1938. In thickets at low altitudes. Distrib. Endemic.

This is no doubt, most closely allied to Kentrochrosia monocarpa LaUT. et K. Schum. from New Guinea (Fl. Deutsch. Schutzg. Süds. 506, t. 18). Though we have not seen the specimen of this species, so far as we can judge from the original description and plate, our species seems to differ from it by its different form of its fruit with much shorter spur. The size and form of the leaves are very variable.

(216) Celtis palauensis Kanemina et Hatusima nom. et comb. nov.

Trema integrifolia Hosokawa in Trans. Nat. Hist. Soc. Formos. 28 (1938) 154.

No. 4858, Arakabesan, Korror, Palau, S. Hatusima, April 11, 1938. 


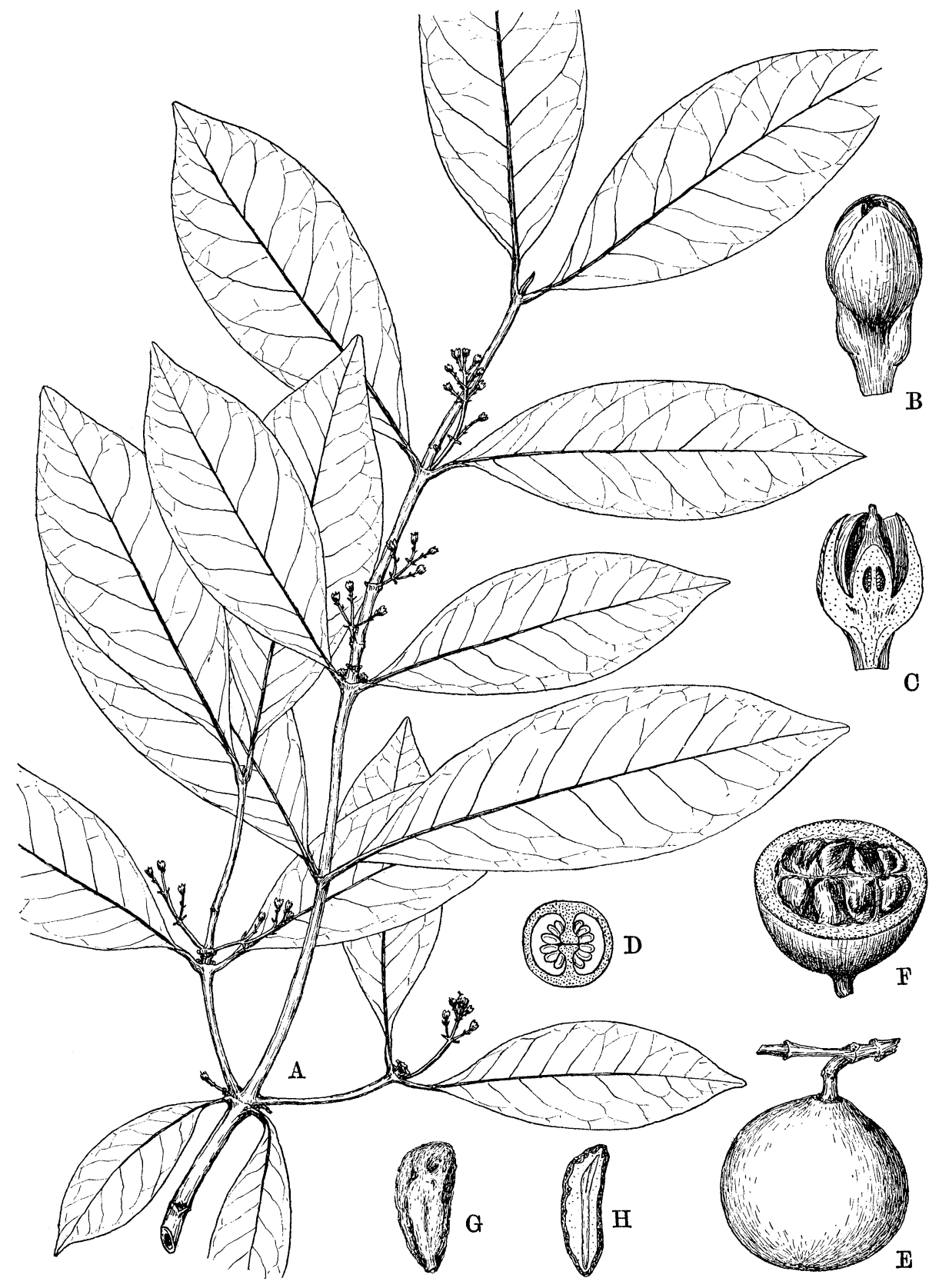

Fig. 78. Clitandropsis insularis MARKGRAF.

A. Branchlet with flowers. $\times \frac{2}{3}$. B. Flower, corolla fallen off. $\times 7$. C. The same in long. section. $\times 8$. D. Ovary in eross section. E. Fruit. $\times 2 \frac{2}{3}$. F. The same in cross section. G. Seed. $\times 1 \frac{1}{3}$. H. The same in long. section. $\times 1 \frac{1}{3}$. 


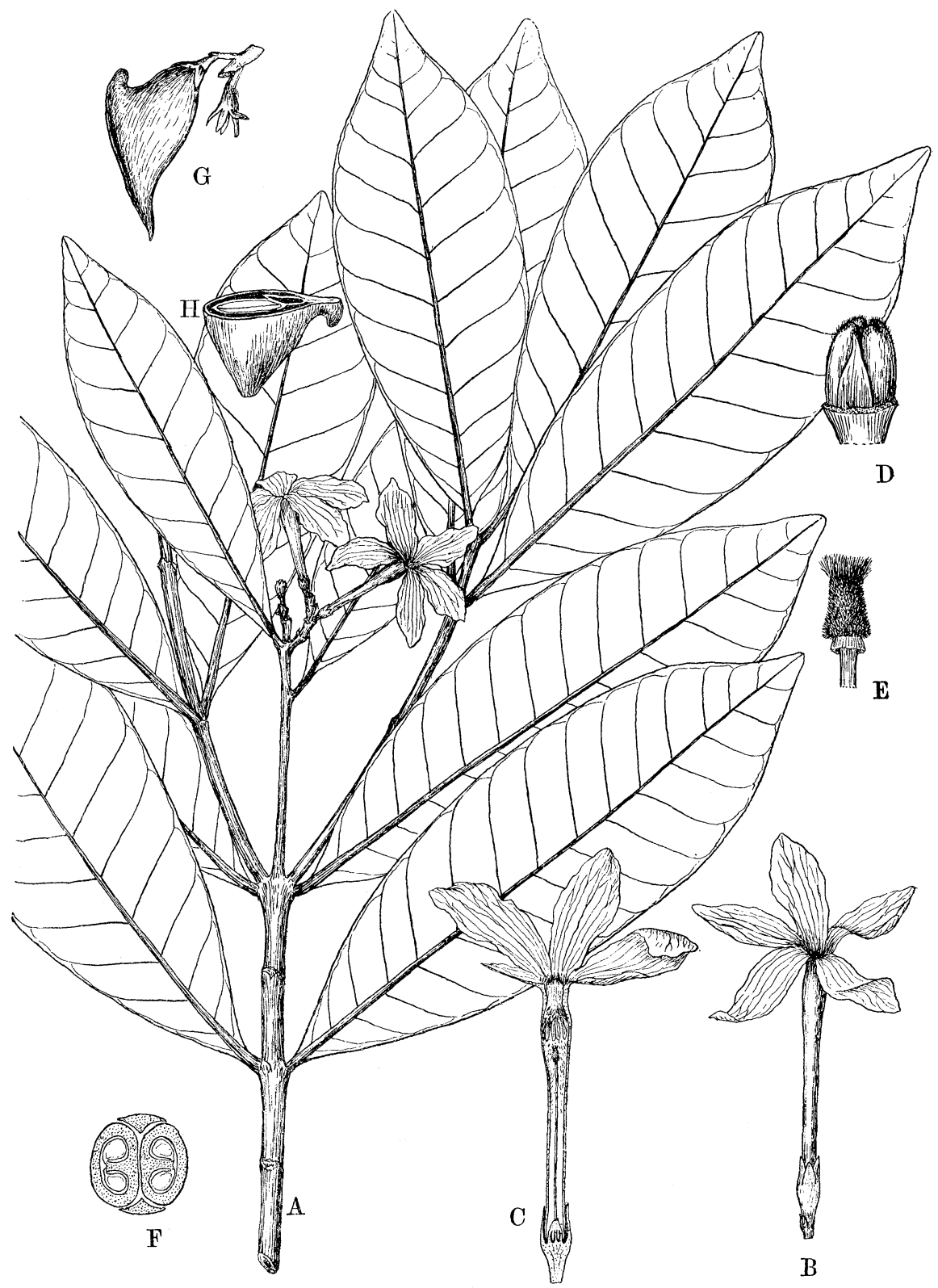

Fig. 79. Kentrochrosia carolinensis KaneH. et Hatusima.

A. Branchlet with flowers. $\times 2 \% 3$. B. Flower. $\times 1$. C. The same in longitudinal section. $\times 1$. D. Ovary. $\times 4$. E. Stigma. F. Ovary in eross section.

G. Fruit. $\times 2 / 3$. H. The same in cross section. $\times 2 / 3$. 
Distrib. Endemic.

We have not seen yet neither the flowering nor fruiting specimen, but we do not hesitate to transfer this species to Celtis, by its leaf character. Specific name integrifolia is preoccupied by Celtis integrifolia Lam.

(217) Psychotria Merrillii KaneH. in Bot. Mag. Tokyo 46 (1932) 674, Fl. Micr. (1933) 371.

Plectronia polyneura Valeton in EngL. Bot. Jahrb. 63 (1930) 309.

Plectronia obovata VaLeton 1. c. 63 (1930) 311, syn. nov.

Canthium Valetonii KAneH. in Bot. Mag. Tokyo 46 (1932) 671, Enum. Micr. Pl. (1936) 416, syn. nov.

Canthium polyneurum KaneH. in Bot. Mag. Tokyo 46 (1932) 672, 49 (1935) 274, photo. 3, Enum. Micr. Pl. 416.

Hab. Ponape. Distrib. Endemic.

(218) Pseudomorus Brunoniana (Endu.) Bur. in DC. Prodr. 17 (1873) 249 ; Diels in ENGL. Bot. Jahrb. 69 (1938) 397.

Malaisia scandens (non Planch.) KANeH. in Bot. Mag. Tokyo 45 (1931) 227, Fl. Micr. (1933) 92, Enum. Micr. Pl. (1935) 308.

Hab. Saipan. Distrib. New Guinea to Polynesia.

(219) Pisonia cauliflora Scheff. in Tijdschr. Nederl. Ind. 32(1871) 417; Valeton in ENGL. Bot. Jahrb. 52 (1914) 102.

Calpidia cauliflora HeimerL in Oesterr. Bot. Zeitschr. 43 (1913) 283.

Pisonia umbellifera sensu KaneH. in Bot. Mag. Tokyo 45 (1931) 278; Fl. Micr. (1933) 100, f. 26, Enum. Micr. Pl. (1936) 316, pro parte-quoad pl. ex Saipan, non Forster.

Hab. Marianne Islands. Distrib. Moluccas to North-western New Guinea. 